источников загрязнения воды в Нигерии. Chemistry Journal Vol. 1, № 5, 2015, c. 159-164.

24. NOSDRA says dead fishes on N/Delta coastline traced to discharge toxic wastes. Available at: https://nigerdeltaherald.com/nosdra-says-dead-fisheson-n-delta-coastline-traced-to- discharge-toxic-wastes/

25.Дэвид Н.О., Феликс И., Икем Э. Управление отходами: инструмент для защиты окружающей среды в Нигерии. AMBIO A Journal of Human Environment 31 (1): 55-57. Февраль 2002 г.

26.European Commission - EU Science Hub Research topic - Environmental monitoring. Available at: $\quad$ https://ec.europa.eu/jrc/en/researchtopic/environmental-monitoring

27.Фишер В.С., Джексон Л.Е., Сутер Г.В., Бертрам П. Показатели для оценки риска для человека и окружающей среды: точка зрения Агентства по охране окружающей среды США. Оценка человеческого и экологического риска, 2001. 7: 961-970.

28.Уилл Роуз, BBC News, Дельта Нигера, 26 июля 2012 г., процветающие нелегальные НПЗ в Нигерии.

Доступно по адресу: file:///C:/Users/User/Documents/The_State_of_Enviro nmental_Monitoring_in\%20Nigeria.pdf

29.Чокор Б.А. Государственная политика и охрана окружающей среды в развивающихся странах, Управление окружающей средой, 1993. Том 17, № 1, c. 15-30.
30.Чокор Б.А. Экологическая осведомленность как стратегия для эффективной экологической политики и контроля загрязнения окружающей среды в вопросах и управлении в нигерийском развитии, Evans Brothers Limited, 2005.

31.Елохин А.П., Ксенофонтов А.И., Пырков И.В. Основы экологии и радиационно-экологического контроля окружающей среды: Учебное пособие под редакцией А.П. Елохина. М.: НИЯУ МИФИ, 2016. - 680 с.

32.Emmanuel Onyeabor, Helen Agu. Economic Based Approach to Environmental Regulation as a Panacea to Effective Environmental Management in Nigeria. Journal of Law, Policy and Globalization, ISSN 2224-3240 (Paper) ISSN 2224-3259 (Online) Vol.42, 2015. pp. 8-17.

33.Уилл Роуз, BBC News, Дельта Нигера, 26 июля 2012 г., процветающие нелегальные НПЗ в Нигерии. Доступно по адресу: https:/www.bbc.com/news/world-africa-18973637

34.Нефть: Заговор, который отнимает у Нигерии миллиарды долларов. Новости Авангарда, 25 Августа 2014 г. Доступно по адресу: https:/www.vanguardngr.com/2013/08/oil-theconspiracy-that-robs-nigeria-of-billions-of-dollars/

35.Federal Republic of Nigeria Official Gazette. Vol. 96, № 65. 2009. Available at: file://C:/Users/User/Documents/ng-governmentgazette-dated-2009-10-14-no-65.pdf

\title{
EDUCATION: EIDOS EXTRACTION OR TECHNOLOGY
}

\author{
Korkiya Eka Demurievna \\ Cand. social sciences, associate professor \\ Moscow State University named after M.V. Lomonosov \\ Moscow, Russia \\ Mamedov Agamali Kulamovich \\ Socialist sciences, professor \\ Moscow State University named after M.V. Lomonosov \\ Moscow, Russia \\ DOI: $10.31618 /$ ESU.2413-9335.2020.7.75.882
}

\section{ABSTRACT}

This article emphasizes that digital technologies have already been totally introduced into education. Digitalization is a global process that every day subjugates the educational space and even beyond. The authors argue that the practice of introducing digital technology affects the modernization of research areas.

Keywords: digitalization of education, technology, virtual world, culture, trends, globalization, the learning process, cyberdependence, prospects.

The mirror is more important than a number of portraits (V. Menzel). There is a common assessment of Deng Xiao Ping of the Great French Revolution, that only 200 years have passed and it is too early to give any final assessments. Perhaps it is. Of course, time is the most honest critic (and this phrase, unfortunately, is also not ours!!). But surely, soon there will be a stream of articles and opuses on the topic - the world after the coronavirus will be avalanche-like. That's right, in the morning in the newspaper, in the evening in the couplet. Or vice versa? I do not want to be in this row. Not an oracle. And to fortune-telling "no respect." Talk about something else. Virus! Involuntarily, the whole country is sitting by the TV. What else to do? Read weaned. It is nice to see how figures of "culture" from their palaces teach everyone how to survive the crisis. But did not try on 64 square meters. meters and without lawns somehow keep the children. Especially if it's the boys. Bored with Cord with Joseph? Well, their TV is at the service. And they will impose their lamentation on the whole country. And the actor's daughter broadcasts throughout the country how to take his mother to a psychiatric clinic. And Guliyev in Spartak rude to the coach. It's necessary to speak about it loudly with all his throat. What else to write? Not about the fate of the repeatedly humiliated and offended? And forever deceived. What tragedy is this ?! But the fact that the oligarchs (the poor, the pre-grandfathers) lost 
because of the crisis, yes !! And they would read Krylov's fable "The Pig Under the Oak" to them. Yes, it's clear that they were not the fairy tales they read as governesses in childhood. But in vain. But Oak broadcasts there: When you could raise the snout up, You should have seen that these acorns grow on me. Or Saltykov-Shchedrin about how a man fed two generals. Yes, and Malchish Kibalchish would not hurt on the shelf. And Gorky with the Petrel. Yes that zhzhzhzh. Back in the New Year, he drew attention to the poverty of our TV. Who are they entertaining? And How? I do not believe in different conspiracies and world governments. What for? We have enough of our own dope. And conspiracy theological scenarios to anything. You just need to realize the general level is already SO. And do not blame anyone. The general level of culture is as follows. It is such that we swallow it. And how. And you like it. Is it difficult to understand Gogol's humor? What for? After all, there is a "Crooked Mirror" or something else. But one must understand that the roots of all this are in those "transformations" of education. When a thinking and active student is replaced by a consumer. Of course, there was still a wide palette of reasons for the intellectual and cultural impoverishment of the nation. But not a single sphere has been subjected to such Atlantic storms. And now, as if grief theorists were waiting for the moment. And let's transfer all education to the virtual world. And that's all. And right away! I understand that many, many people need buildings of schools and universities. And another people are needed. But gentlemen, moderate the ardor. Not at the same price? But there are real risks of losing the remnants of the education that is valued throughout the world. And no one calls for a return to accounts and stylus, but any large-scale act should be justified. At least theoretical calculations. And is digitalization of education so uncontested?

His key ideas are the following:

1) Training is a business area - sale of services. A person buys skills in order to then sell them profitably. A person is considered as a commodity - hence the aspiration for single talents, which are more expensive and bring great profit.

2) A fundamental change in the content and teaching methods. Since "education" should simply be the acquisition of competencies that are currently needed by employers, only part of the subjects are left for normal teaching, the rest, primarily humanitarian ones, are transferred to online training. Fundamental education remains only for a few, it is an expensive, "human" education. For the rest - cheap, "computer", remote.

No studies of "digital education", obviously detrimental to the health and development of children, have been conducted.

Speaking about electronic teaching aids, experts drew attention to the fact that in a disastrous situation with the health of students, unverified technologies are being massively introduced into schools. The physiology of elementary school students has not yet settled down and some of them only need to work with the gadget for 15 minutes in order to lose the ability to hold attention until the end of the lesson. Experts are convinced that only high school students can use gadgets with greater benefit. And if in 10 years the state needs to have a thinking, creative generation that can create, create, invent, when using information technology from a kindergarten, this becomes impossible, since early acquaintance with electronic means kills all these positive qualities. According to the unanimous opinion of experts, it is no coincidence that electronic textbooks, unlike a traditional textbook, do not have any certification and approved standards. There is no evidence of their safety for the health of children, no requirements for their design. In addition, in e-school, children spend a lot of time in headphones, their hearing deteriorates, from luminous monitor screens - vision is impaired, from a sedentary lifestyle at the computer - metabolism, the state of internal organs are impaired, muscle condition is deteriorated, early scoliosis etc. E-school has not yet begun to work, but now less and less attention is being paid to writing. First, calligraphy disappeared, then calligraphy, now thanks to workbooks, handwritten writing is practically reduced to nothing. Obviously, when switching to a digital school, a handwritten letter will be finally buried. What are the consequences of rejecting the letter awaiting schoolchildren and all of us in general? We will begin to read worse. And motor skills and coordination will suffer. With manual writing, brain regions are involved that are responsible for the interpretation of sensory sensations and the formation of speech. And for those who do not write with their hand, these sections are turned on much less frequently. Brock's center is in his head - the section responsible for folding letters into words and recognizing them. That is, for the ability to read and write. With manual writing, this center activates its work. From this, scientists at the Norwegian University of Stavanger concluded that people who write fast read better. And vice versa: people who read slowly and have difficulty understanding the text write poorly. In children who write a little, the eye is poorly developed. And vice versa: those who have problems with the eye, write poorly. In China and Japan, for example, they tried to take calligraphers as archers. People will become worse at recognizing written text. He who does not write by hand himself does not understand what is written. Of course, in a world where no one uses a pen, the inability to read a letter is fearless. But it's scary that we will give up this mental activity. The processes of reading written and printed texts have been thoroughly studied. People with books and notebooks were put in MRI machines, ultrasound scans were performed while reading, Doppler scanning of brain vessels, an electroencephalogram was made. When reading a written text, we have involved much more parts of the brain than when we perceive a printed one. Without writing, we will formulate our thoughts worse. After all, when recording a speech, a person, even before touching a pen with a paper, adds sentences to his mind. In fact, writing by hand requires a higher form of abstract thinking [3, pp. 11-13]. In order to type text on a computer, this is not necessary, because the phrase, case, union can be changed at any time. Everything is very simple: who often writes with his hand and writes 
lectures, often turns to abstract thinking. And he also needs to be kept in good shape.

We will have a bad imagination. People who write text by hand have a better idea of what they are talking about in their minds. If this is a lecture on poets of the Silver Age, students who write on paper more closely represent the members of the "Jack of Diamonds" and the characters of Yesenin's poems than those who type on a computer. Children, in principle, will become worse at learning and remembering. There are many studies that say that material written by hand, and not on a computer, is better remembered, as people formulate the main thoughts in the recording process.

On a computer or tablet, you can do almost everything the same, but a person no longer needs to clearly think through the thought and structure of the text, because he can add something at any time. To master the material, it was enough to record a lecture well - no need to re-read. Today's students and schoolchildren, in preparation for exams, have to reread the notes several times. Already, many tasks at school involve finding information on the Internet. This leads to the fact that children quickly get used to finding answers on the net, and as a result get used to fast reading, without going into the bottom line. People of all ranks and specialties complain about problems with the perception of information. Such complaints can be especially often heard in the academic environment, i.e. from those who, by occupation, are forced to communicate closely and daily with people (to teach, give lectures, take exams) - they report that the already low level of reading and perception of information from those with whom they have to work, from year to year falls lower and lower.

It is known that the average Internet user reads no more than $20 \%$ of the text placed on the page, and in every possible way avoids large paragraphs! Moreover, special studies have shown that a person who is constantly connected to the network doesn't read the text, but scans like a robot - snatches out scattered pieces of data from everywhere. In the course of research, it turned out that the pages on the Internet, as already mentioned, are not readable, but are scanned fluently according to a template resembling the Latin letter F.

The user first reads the first few lines of the text content of the page (sometimes even completely, from beginning to end), then jumps to the middle of the page, where he reads a few more lines (as a rule, only partially, without reading the lines to the end), and then quickly goes down to the very bottom of the page - see "how it ended." It is unlikely that there will be a person who would not hear the popular network saying "too many letters - did not master", It turns out a vicious circle - there is no point in writing, because almost no one will read it, and the reduction in the amount of transmitted thought leads to even more stupidity not only readers, but also writers. As a result, we have what we have - mass dullness. It is now known that iPads, smartphones and Xboxes are a form of digital drug.

Recall that training is planned to be carried out using a tablet, which is essentially the same. Recent studies of brain scans show that they affect the frontal lobe of the cerebral cortex - the dopamine-controlling system responsible for rewards, attention, and shortterm memory - just like cocaine. Such technologies stimulate brain activity so much that the level of dopamine, the neurotransmitter responsible for the fee involved in the formation of addiction, rises in the body as much as during sex. It is because of this addiction effect that Dr. P. Weibrau, director of the Department of Neuroscience at the University of California, calls the screens "electronic cocaine," and Chinese researchers call them "digital heroin." The brain of your child playing Minecraft looks just like the brain under drugs. It is not surprising that it is so difficult for us to tear kids off the screens and children are so annoyed when their game with gadgets is interrupted. Hundreds of clinical studies show that gadgets increase depression, temper, and aggression and can lead to psychotic consequences in which the player loses touch with reality [4, pp. 201-205].

When a person crosses the line of addiction whether it is drugs, digital technology or something else - he needs to undergo detoxification before any treatment can help him. In the case of technology, this means no computers, smartphones, tablets. Now most children, in one form or another, suffer from screen addiction. As stated above, there is only one way out no gadgets. It is clear that in a digital school this will be completely impossible, the child will be on the tablet all day long for the duration of his studies, which means that screen addiction will only progress.

Not so long ago, about 5-10 years ago, everyone laughed at computer scientists, they were always seen as non-communicative, closed, not particularly communicating with anyone, immersed in their digital world. And not without reason, but now these jokes have disappeared somewhere, guess why? It's just that such people have now become the majority, and society has accepted this as the norm. Most students suffer from loneliness and cannot live without social networks. The personality of the child is formed in the process of interaction with the outside world. Here, the emotional participation of the environment where the person is formed is of paramount importance. When our children sit on the Internet, in social networks - this is a substitute, surrogate form of communication. It will be difficult for such adolescents to build human rather than virtual relationships. The ability to respond to conflicts, as well as to get out of them, to sacrifice something - this is the range of psychological characteristics without which the aggregate personal adaptive potential is imperfect. The identities of children who do not surf the Internet are formed in violent games, which then appears in life. The child is becoming more autistic. In reality, it is difficult for such a child to make friends and communicate with other boys and girls. Children become emotionally dull, communication with living peers, with the living real world becomes unnecessary, because the computer world is already dragging them to its depths. This is the most severe form of mental disability, which so far does not know how to treat, nor psychologists, nor psychiatrists, nor therapists. Narcologists say drug addiction is easier to overcome than cyber addiction. A 
study conducted by American scientists proved that a child who spends at least five days without mobile phones, a computer and a TV, improves social skills. "You will not be able to recognize non-verbal emotional signals from the blue screen in the way you would do face to face with another person," says one of the scientists. "If you don't practice live communication, you can quickly lose the most important social skills." Children receive emotional training from two major sources. The first is reading good literature.

It is from there that children draw complex patterns of behavior, learn subtle motives for actions. Living together with the heroes of their joys and troubles, children complicate their emotional arsenal, make it richer and more diverse. But how many children are reading books now? Many more are those who limit their communication to virtual toy characters, walking pictures. In this virtual colorful world, imagination does not need to work - everything was invented for you. The characters are simple, understandable, soulless. They can be destroyed in hundreds, they obey the slightest movement of your fingers. "What will result in a lack of development of social skills for a child? Inability to interact with society, inability to understand others and to make you understood. Such children grow up with a low tolerance for manipulation - because they are impulsive and have a rather poor spectrum of emotional reactions. But the most important thing is that in adulthood they will face loneliness and alienation. In Germany, bestseller lists are led by Digital Dementia. How we deprive the mind of ourselves and our children. "Its author Manfred Spitzer is the director of a psychiatric university clinic in Ulm, Germany. "According to research findings, a computer is needed for training, like a bicycle for swimming or an X-ray machine for trying on shoes," said Spitzer. And the Internet and other electronic toys primarily harm children. When the era of television began, scientists warned that three hours spent at the screen increase the risk of weight gain and a tendency to aggression. And it really happened. What can I say now, when young people are in the digital world 7.5 hours a day? Digital technology saves us from mental work. It is not worth reminding that an organ that is not used dies. Unused connections between neurons in the brain weaken. This is exactly what happens in the head of an internet addicted person. People using Google and Wikipedia do not remember information, but only where it can be found. Advanced digital technologies adversely affect spatial orientation. London taxi drivers should have known by heart 25 thousand street names and thousands of squares, during training, they increased those areas of the brain that are responsible for orientation. Now drivers use the satellite navigation system, as a result, it is becoming increasingly difficult for them to find their own way or figure out the map.

The Internet also affects memory: phone numbers and addresses are written to computers and mobile phones, Facebook reminds about the birthdays of relatives and friends. "Mnemonic processes no longer occur in our brains, as we transfer them to electronic devices," Manfred Spitzer draws attention. It becomes harder to learn. Anyone working with the Ctrl-C + Ctrl$\mathrm{V}$ method does not take any mental effort and quickly forgets everything. Children do not receive sensory stimuli (taste, smell, touch). Using video, it's impossible to learn to speak well, because the sound and lip movements are not as perfectly synchronized as in life. Despite all this, it is with digital technologies that our children are offered to replace almost everything. The use of wireless networks in schools and kindergartens is dangerous for the health of children, however, this technology is implied during training. In May 2011, the World Health Organization's International Agency for Research on Cancer (IARC, an intergovernmental organization within the WHO's UN headquarters in Lyon, France. She is involved in epidemiology and research on the causes of cancer as an interpreter) assigned EMR RF to group 2B carcinogens. that is, "probably carcinogenic" to humans. Since then, there have been other scientific studies on the effects of radiofrequency radiation on humans, animals, and biological materials that have reinforced the conclusion that radiofrequency radiation is associated with an increased risk of cancer, especially brain tumors. In a series of laboratory studies, mechanistic factors were identified that influence the likelihood of developing cancer, including oxidative stress, decreased expression of messenger RNA, and single-stranded DNA strand breaks.

For children, the risk can be enhanced by the effect of accumulation throughout life. Developing and immature cells may also be more sensitive to the effects of EMR. A safe level of radiation has not been established by any healthcare organization, so we have no confidence in safety. In addition to the risk of developing cancer, radiofrequency radiation may also affect the blood-brain barrier, opening the way to toxic molecules in the brain, damaging neurons in the hippocampus (the center of the brain's memory). Studies have also found cognitive impairment affecting learning and memory. The results of the study of the educational achievements of PISA in reading and mathematics, conducted by the Organization for economic cooperation and development, show a decrease in the results in countries that have invested the most in the implementation of computers in schools [1].

Add to this the radiation from metal detectors, which are already installed in many schools. Gadgets develop dyslexia in children. Among younger schoolchildren, up to 30 percent of children suffer from dyslexia and more than 37 children with dysgraphia, whose tongues are tangled when reading, and letters are exchanged when writing, it is more than the "pre-gadget" time. About a third of primary school children suffer from dyslexia, and dysgraphia - more than $37 \%$. Because of this, children lose interest in learning. Such children in the world, according to UNESCO, about 300 million, five percent of them cannot get a job in life. Not the best way the situation is affected by constant "freezing" in the phone, "says Natalya Svobodina, a speech therapist and practical psychologist:" If a child is hyperactive, he has problems concentrating, then the later he picks up the gadget, the better it will be ". 
According to the psychologist, in this situation there are two recipes: for specialists there is a rather simple advice: ask students for help, only do it sincerely. Many with these problems turn to a speech therapist, but he can not always help. Sometimes a psychologist is required, and perhaps even a neurologist. Such a child can be helped, but dyslexia and dysgraphia do not completely disappear. Over the past decade, oral language has been aggressively pushed out of the learning process. A test of knowledge in oral subjects is replaced by a check of workbooks, in which you just need to enter the necessary words from the paragraph. In workbooks on geometry (think about it, this is an object that forms spatial thinking, evidence, reasoned thinking) the solution to the problem has already been printed, the students are only required to enter the necessary angles or sides. What to complain that young specialists are not able to set goals for themselves, cannot independently compose an algorithm for solving a given problem? Thinking and speech are closely interconnected: active oral speech forms thinking, thinking, developing, improves speech. And all this with the active coordinated work of all parts of the brain.

Delayed speech development in children. The clinic conducts medical examinations of a child psychiatrist at 2 years old. Of 10-15 children coming to the reception, only 1-2 children can name a familiar animal, many two-year-old children use only 5-10 words in their speech (mom, dad, woman, give, drink, am-am - the norm of one-year-old children for a generation of current parents), although they understand conversations well (bring the right toy, can show parts of the body). The question is: why? The answer is obvious on the streets of the city: most mothers carry a stroller with one hand, and hold a smartphone in the other: the child stares at the sides, and mother has an interesting time, and if she needs to answer the babble babble - she answers without taking her eyes off the screen. And here lies the root of the problem: for a child to develop speech, it is not enough for him to hear it, he must see the facial expressions and articulation of his mother, so that his own articulation will be activated due to the work of "mirror" neurons. No audio toys, "repeat toys," no Internet programs will teach a child to speak if he does not see the face of the talking person. The capabilities of "mirror" neurons have not yet been fully explored, there are many myths around them, but one thing is certain: it is the "mirror" neurons that convey speech skills, the skills of mental operations (comparison, analysis, synthesis - these mental operations are poorly developed in students who are behind) adult to child. Exactly so: the "mirror" neurons of an adult transmit information to the "mirror" neurons of the child, which, in turn, start the work of the necessary zones of the cerebral cortex. If the information will be supplied to the child from another source, the "mirror" neurons will not turn on. The same thing happens during the educational process: if the teacher's "mirror" neurons did not participate in the supply of educational material, the brains of the students will not turn on. Try to replace the teacher's explanations of the new material with an audio recording, and then give the students test work.

But this is exactly what is being proposed. In all the digitalization programs of the school, the role of the teacher is decreasing every year, it is planned to replace the Teacher - as an example and a role model - with a virtual "tutor". There are sanitary standards where it is prescribed that in grades 1-4 the child can continuously work on the computer for no more than 15 minutes. When switching to digital training, this time, taking into account homework, will be 5-6 hours minimum. According to studies by American scientists, the risk of vision problems in people who spend more than 3 hours a day at the computer is $90 \%$ ! Another important point, the smaller and worse the screen, the more you have to strain your eyes. Therefore, for example, a computer monitor is better than a tablet, but it is planned to use tablets in training, taking 5-6 hours a day.

Expert commentary: The screen image differs from the paper one in that it is self-luminous, consists of individual dots (pixels), has no clear boundaries and relatively low contrast. While working at a computer, our eyes are close to the monitor. The insufficient illumination of the workplace and the need to constantly move your eyes from the screen to the keyboard and vice versa only exacerbate the situation. Therefore, daily long-term work at the computer can spoil the vision: lead to blurred vision, pain in the area of the orbits, forehead, eyes when they move and cut in them, dry eye syndrome, accommodation spasm and subsequently myopia (myopia), progression already existing myopia. Children and people with myopia, astigmatism and farsightedness are especially sensitive to such visual stress. If you carefully read the fundamental project childhood 2030, then computer game forms of instruction are prescribed there, namely: a school as a digital game space with augmented reality, here the children will be happy. This is already the full end of education, how can you then explain to the child the harm of computer games when they are used in school and will be part of the education, although this can no longer be called education.

In 2020, it is planned to completely eliminate paper textbooks in 11 school subjects, replacing them with "certified personal access devices in the prescribed manner. It is unlikely that anyone will disagree with the fact that the school textbook was and is the most powerful organizer of a multi-million civil nation. Take away from our children's childhood these only books that unite them for life, and we will get a generation "out of context". It will be educated, but it will not be a carrier of common meanings, general ideas about the heroes and antiheroes of its people, its country. They will not be able to feel like citizens, because civic conscience and civic responsibility are feelings, first of all, "Researchers from Dartmouth College found that, depending on the type of information carrier, a person perceives the information received in different ways. The type of carrier, according to scientists, has an impact on the abstract thinking of a person. When reading from the screen of a tablet or laptop, we focus more on the details, rather than the general picture of what is happening. In the 
course of research, scientists carried out a series of experiments to analyze the speed of decision-making and the quality of perception of the text. For this, volunteers aged 20 to 24 years were involved. Representatives of one group were given texts printed on paper, while others were given laptops with a pdffile open on the screen. As a result, it was concluded that those who read the printed text responded much better to logical questions in the text. Group successes were $66 \%$ versus $48 \%$, respectively. Further, the task was complicated. The participants were given a look at the table of characteristics of four conventional vehicles. At the same time, each characteristic was indicated by an assessment ("excellent", "adequate"). But one of the models was objectively better than the rest in basic parameters. And here it turned out that those who read the text from paper often correctly determined the best option (48\% of cases) than participants with laptops (only 30\%).

That is, the child, when using the tablet, will be able to complete tasks, but will not be able to draw complex conclusions, and will not see the connections and the big picture. The quality of such training will be lower at times.

Add to this the abolition of the usual, and the introduction of electronic diaries, destroy one of the most important principles of learning - visibility.

However, existing legislative norms are still oriented towards the traditional approach preservation of the nuclear family - and contradict modern trends in the formation of other types of life together. In these circumstances, children and parents become hostages of the situation [2, p.30].

In the near future, these trends will only intensify and the development of a new family code and legislative support focused on various forms of the family and life together becomes more relevant than ever. Thus, we could save children from dependence on outdated forms and stereotypes ... ". "For a modern parent, a child becomes a difficult project. A woman is forced to choose: work or children? Combination is not possible. On the other hand, the child receives incompetent parents, who even find it difficult to provide first aid, not to mention psychological support, a life together in which the child would not be depressed. In our opinion, parental knowledge should be given at special sites. Parenting education should be at least affordable. But in principle, we can go further it should become mandatory. And with appropriate reform of the guardianship authorities and social services, we will have to raise the issue of restricting parents' rights in some time if they have not passed this training or do not fulfill their responsibilities to the child ... "It should be noted that the transition to universal digitalization of education begins when a wide discussion of the catastrophic consequences of the introduction of e-schools is just beginning in the West. Recently, the New York Times published information on the topic: "A school without technology in Silicon Valley." The article reports that in the educational process of the school, which is attended by the children of employees of technology giants such as E-Bay, Google, Apple, Yahoo, Hewlett-Packard, technology products are not used at all, and preference is not given to computer screens or interactive whiteboards, and old boards made of wood, chalk, paper, pen. Why does a man protect his children from what he produces? The answer to this question can be found in the expression of a senior Google employee Alan Eagle: "The idea that using an App or iPad to better teach my child to read or math is ridiculous." Eagle notes that his daughter, a 5th grade student, is still «unable to use Google».

Instead, like her other classmates, she is trying to perfect her sewing skills. According to Alan Eagle, learning how to use technology is as easy as learning how to brush your teeth. Eagle sums up: "We simplify Google or any other product to such an extent that even people with the lowest intellectual level can freely use it. The fact that, having become adults, our children will not be able to use technology, there can even be no question."

Evan Williams, founder of Blogger and Twitter, says their two sons also have similar restrictions. There are hundreds of paper books in their house, and every child can read them as much as they like. But with tablets and smartphones it's becoming more difficult they can use them no longer than an hour a day. The journalist of The New York Times Nick Bilton during an interview with Steve Jobs asked him a question: do his children love the iPad. "They do not use it. We limit the time that children spend at home on new technologies, "he said. The Jobs family even banned the use of gadgets at night and on weekends. Other "gurus" from the world of technologies act in a similar way [5, p. 80]. The fact that the minds producing technological innovations are making such efforts to protect their children from them is indeed of great importance. And what can our state and educational institutions say about our crazy race to introduce children to modern technologies. A lot of money is being spent on digitalization of schools, but you understand, nothing is done right now, everything now comes from profit, and only from it, it is now set as the main value. It's like at a factory, when new expensive equipment is bought, it is not bought at all so that the products are of better quality, but in order to fire several people. Now they are not needed, there is an automatic machine, it is much cheaper, he does not need to pay a salary and sick leave, and he pays off in a few years. So it is here. After the introduction of these technologies there will be a reduction in teachers, their replacement by tutors, intermediaries between the student and the training program, this is not hidden in the project. In foresight, much emphasis is placed on online courses, this word is found there regularly, naturally, a teacher in this format will also not be needed.

In the end, I would like to write about the last paragraph of the Foresight "Childhood-2030". If you start to study this topic, and enter the childhood of 2030 in the search engine, then most likely, the first 10-20 tabs will have the name "chipping children into the brain." Indeed, there is such a point, and if in a nutshell, it implies loading educational programs directly into the brain using the chip installed there, almost like in a matrix. 
In addition, the "Strategy for the Development of the Electronic Industry of the Russian Federation until 2025 " explicitly provides that "A constant connection of each individual with global information and control networks such as the Internet must be ensured. Nanoelectronics will integrate with bio-objects (the socalled people) and provide continuous monitoring of the maintenance of their life ...

The first option - you decide that all this is marginal nonsense, which means that everything related to the criticism of digitalization is also rumor and horror stories, you should not believe all this, everything is fine with us.

The second option - a person goes into the study of the topic of precisely chipping, and finds a sea of video of very, very dubious content, pressing on emotions, and not on the mind, instead of studying the phenomena in education that actually occur, already here and now. If you study the topic of chipping purely from a technical point of view, then such technologies that are shown in most videos are not yet available, and are not expected in the near future, this is actually not so simple. Moreover, if in fact there were such technologies, and such plans, then we would certainly not have been told about them. Of course, this does not mean that there can be no chipping - it can, but still it is much more important to pay attention to the fight against more important things that are happening now. Such as the introduction of tablets, electronic diaries, educational trajectories, tutors, and other educationdisruptive programs. It is necessary to solve problems as they become available, it is no coincidence that the stage of chipping is recorded last in the foresight, all because it will become possible only if the parents first accept everything else.

\section{References:}

1. Andrianova G.A., Khutorskoy A.V. Creativity in distance education - Abstracts at the conference "RELARN-98". 1998. http://www.relarn.ru:8080/conf/conf98/rep103.html

2. Butsyk S.V. "Digital" generation in the educational system of the Russian region: problems and solutions // Open Education. No. 1. 2019.S. 27-33.

URL: https://cyberleninka.ru/article/n/tsifrovoepokolenie-v-obrazovatelnoy-sisteme-rossiyskogoregiona-problemy-i-puti-resheniya.

3. Korkiya E.D., Mamedov A.K. Identity in virtual reality: new alternatives // Theory and practice of social development (electronic journal), No. 2, 2017. P. 9-13.

4. Mamedov A.K. Epistemology of social cognition. M., 2017.

5. Omarova S.K. Modern education trends in the digitalization era // Pedagogy. Issues of Theory and Practice, No. 1 (9), 2018. P. 78-83.

URL:

https://cyberleninka.ru/article/n/sovremennyetendentsii-obrazovaniya-v-epohu-tsifrovizatsii. 